\title{
免疫病の分子治療 (抄録)
}

\section{大阪大学医学部内科学第三講座 岸本忠三}

生体に抢ける免疫のはたらきは大さく“認識”と“調 節”に分けることが出来る.Tリンパ球による抗原の認

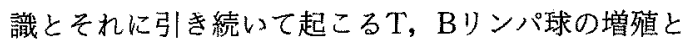
エフェクター細胞 (キラーT細胞, 抗体産生細胞)への 分化である。“認識”にかかわるTリンバ球レセプター (TCR) とMHC，リンパ球の增殖と分化を“調節”す るサイトカインとそのレセプターは殆どすべてその構 造が解明された。外来抗原は抗原提示細胞（マクロ ファージやB紬胞)に取り込まれ，処理され，約 $9 \supset の$ アミノ酸より成るペプチドがMHC分子と結合して細 胞表面に提示され，このMHC-抗原ペプチド複合体を Tリンパ球が認識する，自己抗原と反応するTリンパ 球は胸腺内で発生の過程に消去されるか, 又は末梢で アナジーに松ちいると考えられている。

$\mathrm{TCR} \beta$ 鎖の可変領域 $(\mathrm{V} \beta)$ はその構造類似上からい くつかのファミリー $(\mathrm{V} \beta 1, \mathrm{~V} \beta 2 \cdots)$ に分けられる. ある種のウイルスや細菌抗原(EBウイルス, 黄色ブド ウ球菌，マウス乳癌ウイルス等)はV リーに属する全てのТリンパ球と反応することが明ら かとなり，これをスーパー抗原と呼ぶ。何らかのスー パー抗原がヒトの免疫病（例えばリウマチ，クローン 病, サルコイドーシス等)においてTリンバ球の活性化 と病気の発症にかかわる可能性が考えられる.

“認識”に引き続いて起こるリンパ球の増殖と分化, あるいは抗体産生，炎症等のエフェクター効果発現は インターロイキン，あるいはサイトカインと呼ばれる 分子によって調節されている。 サイトカインは免疫・ 血液・脳神経系の機能発現に重要な役割を果たすと共 に，その異常産生は種々の病気の発症に深くかかわっ ている，炎症症状の発現はIL-1，IL-6，TNF，IL-8等 の炎症性サイトカインによって全て説明出来るといっ ても過言ではない。

このように過去 20 年間の免疫学の進歩は神秘的にさ え見皃た“兔疫のしくみ”を分子，遺伝子のレベルで 解明した。しかし“免度のしくみ”が狂うことによっ ておこると考えられる多くの病気（リウマチ，SLEを はじめとして, クローン病, サルコイドーシス, 肺線
維症, 多発性硬化症, 等) の本態とその発症機構屾い まだ不明の点が多く，従って，本態にのっとった治療 法怡確立されていない.

このような免疫病の発症機構を現時点での免疫学の 知識に基盤を置いて考光ると図のようになる。従って， 免疫病には 2 つ方向からのアプローチが必須である (図).1つはTリンパ球の認識レベルでの解析である. 免疫病に抢ける自己抗体の存在は多数報告されている が, これは多分免疫系活性化の最終的な結果をみい るものであり, 最も重要なものは恼ンハ球により認 識される自己抗原エピトープであり，これはいまだ 1 つとして明らかになっていない.ある病気では細菌・ ウイルス由来のスーパー抗原もТリンパ球の最初の引 き金として考えられるであろう。自己抗原が明らかに なれば，抗原エピトーブを構成するアミノ酸に变異を 導入して認識レベルでの拮抗阻害が試みられる.すで に実験的自己免疫性脳脊髄炎でその有效性が証明され ている.

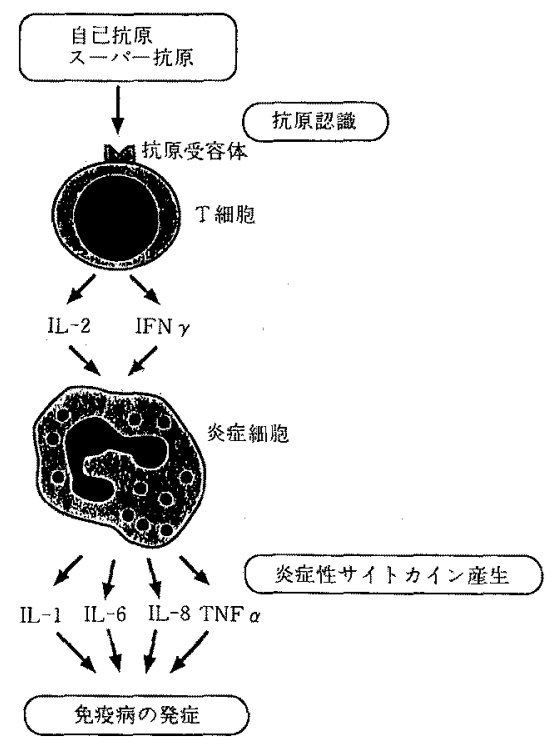

图. 免疫病発症のメカニズム 
もう 1 つは岉論病気の発症にかかわるサイトカイン の産生制御，インヒビターの開発である. HTLV-1ウ イルス由来tax遺伝子トランスダニックマウスやAIDS 患者にリウマチ類似の関節炎が起こることは, リウマ チの発生にウイルスによるサイトカイン異常産生が関 与している例もあることを示唆している。ウイルス感 染がどのようにしてサイトカインの異常産生を誘導す るかというメカ二ズムも転写因子のレベルで明らかに なるであろう、レセプターから転写因子へ，そして遺 伝子発現へと至るプロセスの解明はいずれかのステッ プを特異的にブロックしうるインヒビターの発見につ ながっていく可能性が考无られる。それは丁度サイク ロスポリンAからサイクロフィリン，カルシニューリ ンそしてIL-2遺伝子転写因子 (NF-AT) へという研究 成果の1例に見られるものであり, 転写因子の研究か らステロイドに変わる特異的な抗炎症分子が発見され る可能性がある．以上述べた学問的背景を基盤にし， 我々が明らかにせんとする目標は，
1. 免疫病 (リウマチ, 肺線維症, クローン病, 多発 性盈髄腫，I型糖尿病）に招いて，

a）Tリンパ球はこれら病気の発症に関与するか，そ れはどのようなメカニズムによって活性化されるか.

b）その結果，どのような機構で病気がひきおこさ れるか，エフェクター分子は何か。

2.病気をひきおこすサイトカインの産生は,どのよ うにして調節され，又，その情報はどのようにしてレ セプターを通して標的細胞内人伝達され最終的な機能 発現あるいは病気の発症に至るかという問題である。 ここでは，i）免疫病患者の細胞組織の解析より閔題 を提起し，ii）シグナル伝達，遺伝子発現に関する分 子生物学的研究へと連結し, iii）トランスゲニック， ノックアウトマウスの手法を応用して遺伝子のin vivoでの役割解明，iv）そして最終的に免疫インター ベンションによる治療のモデルとしてりウマチの抗 TNF-a抗体治療，多発性骨髄腫の七卜型化抗IL-6抗体 治潦について語る予定である。 